\title{
A Review on Different Analytical Methods: Letrozole
}

\section{Peethala Prathyusha and Raja Sundararajan*}

GITAM Institute of Pharmacy, GITAM (Deemed to be University), Visakhapatnam, Andhra Pradesh, India

*Corresponding Author: Raja Sundararajan, GITAM Institute of Pharmacy, GITAM (Deemed to be University), Visakhapatnam, Andhra Pradesh, India.

DOI: $10.31080 /$ ASPS.2020.04.0488
Received: January 18, 2020

Published: January 27, 2020

(C) All rights are reserved by Peethala

Prathyusha and Raja Sundararajan.

\begin{abstract}
Letrozole is a third-generation aromatase inhibitor used for hormonal-sensitive breast cancer in postmenopausal women. Several analytical methods were developed to analyze Letrozole. The present review clearly covers all the analytical techniques used for the analysis of Letrozole available till date, which helps the researchers in developing new methods for estimation of Letrozole by considering the pros and cons of the previously developed methods.

Keywords: Aromatase Inhibitor; UPLC; LC-MS/MS; Capillary Zone Electrophoresis
\end{abstract}

\section{Introduction}

Letrozole (Figure 1) is chemically known as 4-[(4-cyanophenyl)-(1, 2, 4-triazol-1-yl) methyl] benzonitrile, with molecular formula $\mathrm{C}_{17} \mathrm{H}_{11} \mathrm{~N}_{5}$ and is freely soluble in dichloromethane; slightly soluble in ethanol; practically insoluble in water. It is a third-generation aromatase inhibitor used for hormonal-sensitive breast cancer in postmenopausal women. A very low daily dose of Letrozole is sufficient for unveiling antitumor activity and it is highly potent and selective and well tolerated [1]. Aromatase inhibitors can be classified based on their chemical structure as steroidal (type I inhibitors) and nonsteroidal (type II inhibitors), where anastrozole and Letrozole are nonsteroidal inhibitors and exemestane is a steroidal inhibitor [2]. Catalysis of enzyme aromatase was the final step in biosynthesis of estrogen so this step can be inhibited for inhibition of estrogen production [3].

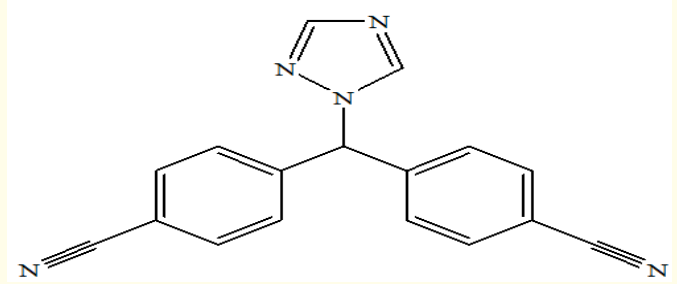

Figure 1: Structure of Letrozole.
Letrozole which is a nonsteroidal type II aromatase inhibitor, interacts noncovalently with the heme moiety of aromatase and occupy its substrate-binding site, thus it inhibits binding of androgens to the catalytic site. It is a reversible antagonism in which the compound can be competitively displaced from the active site by endogenous substrate. According to pharmacodynamics studies the recommended dose of Letrozole is $2.5 \mathrm{mg}$ daily once. Pharmacokinetically, Letrozole was rapidly and completely absorbed after oral administration with bioavailability of $99.9 \%$. Apparent volume of distribution was $1.87 \mathrm{l} / \mathrm{kg}$ (range, 1.47-3.24). About $60 \%$ of Letrozole gets bound to plasma protein mainly to albumin (55\%). The half-life of Letrozole is 42 hours and is longer with great AUC in breast cancer patients. Letrozole gets metabolized by CYP 450 isoenzyme (CYP3A4 and CYP 2A6) and gets eliminated from the body. Steady-state concentrations of Letrozole are reached after 2-6 weeks and maintained for long periods with no evidence of drug accumulation.

Method development and validation can be done using different instrumentation techniques such as spectrophotometric techniques, chromatographic techniques and by some hyphenated techniques. The aim of present work is to review different instrumentation techniques such as HPTLC [4], spectrophotometry (Table 1) [5-10], RP-HPLC (Table 2) [11-24], UFLC [25], UPLC [26] in pharmaceutical formulations and biological samples (Table 3) [27-31], LC-MS/MS (Table 4) [32-39] and Capillary zone electrophoresis [40] for the quantification of Letrozole. 


\begin{tabular}{|c|c|c|c|}
\hline Reagent & $\lambda(\mathrm{nm})$ & $\begin{array}{c}\text { Linearity } \\
(\mu \mathrm{g} / \mathrm{ml})\end{array}$ & Ref \\
\hline Ethanol & 240 & $1-10$ & {$[5]$} \\
\hline Acetonitrile & 240 & $1-24$ & [6] \\
\hline Methanol & 238 & $2-20$ & [7] \\
\hline Phosphate buffer (pH 6.8) & 240 & \multirow{2}{*}{$0.5-20$} & \multirow{2}{*}{ [8] } \\
\hline Phosphate buffer (pH 3.8) & 245 & & \\
\hline Methanol & 240,224 & \multirow{3}{*}{$0.25-20.0$} & \multirow{3}{*}{ [10] } \\
\hline (Zero order, First derivative & 241 and & & \\
\hline Second derivative and AUC) & $235.0-245.0$ & & \\
\hline
\end{tabular}

Table 1: Review of spectrophotometric methods.

\begin{tabular}{|c|c|c|c|}
\hline Mobile phase (v/v) & $\lambda(\mathrm{nm})$ & $\begin{array}{c}\text { Linearity } \\
(\mu \mathrm{g} / \mathrm{ml})\end{array}$ & Ref \\
\hline $\begin{array}{l}\text { Water: Acetonitrile: Phosphate } \\
\text { buffer (pH 5.8)(70:20:10) }\end{array}$ & 230 & $600-1400$ & [11] \\
\hline $\begin{array}{l}\text { Methanol: Tetrabutyl ammonium } \\
\text { hydrogen sulfate }(80: 20)\end{array}$ & 240 & $0.5-150$ & [12] \\
\hline $\begin{array}{l}0.01 \text { M Potassium dihydrogen } \\
\text { phosphate : Methanol }\end{array}$ & 230 & $0.01-80$ & [13] \\
\hline Water: Acetonitrile (30:70) & 230 & $\begin{array}{c}0.0115- \\
1.278\end{array}$ & [14] \\
\hline $\begin{array}{l}\text { Deionized water: Acetonitrile: } \\
\text { Methanol (50:30:20) }\end{array}$ & 240 & $1-50$ & {$[15]$} \\
\hline $\begin{array}{l}\text { Acetonitrile:50.0 mM Phosphoric } \\
\text { acid solution } \\
\text { (pH-7) (50:50) (Fluorimetric } \\
\text { detection) }\end{array}$ & $\begin{array}{l}256(\mathrm{Ex}) \\
585(\mathrm{Em})\end{array}$ & $\begin{array}{l}50-700 \\
\mathrm{ng} / \mathrm{ml}\end{array}$ & {$[16]$} \\
\hline $\begin{array}{l}\text { Potassium dihydrogen phosphate } \\
\text { (pH } 3.5 \pm 0.2 \text { ) with orthophospho- } \\
\text { ric acid: methanol ( } 85: 15 \text { ) }\end{array}$ & 230 & $20-120$ & [17] \\
\hline $\begin{array}{l}\text { Glacial acetic acid: Acetonitrile: } \\
\text { Water }(0.1: 50: 50)\end{array}$ & 240 & $1-100$ & [18] \\
\hline $\begin{array}{l}\text { Mixture of Acetonitrile: Water } \\
(50: 50) \text {. }\end{array}$ & 265 & $160-240$ & [19] \\
\hline $\begin{array}{l}\text { Acetonitrile : Phosphate buffer } \\
\text { (pH 7.8) (70:30) }\end{array}$ & 232 & $10-100$ & [20] \\
\hline Acetonitrile: Water (50:50). & 265 & $160-240$ & [21] \\
\hline $\begin{array}{l}\text { Acetonitrile: Water: Methanol } \\
(50: 35: 15)\end{array}$ & 289 & $4-24$ & {$[22]$} \\
\hline Water: Acetonitrile (60:40) & 240 & $\begin{array}{c}0.25-16 \\
\mathrm{mg} / \mathrm{L}\end{array}$ & [23] \\
\hline $\begin{array}{l}\text { Acetonitrile: Acetate buffer }(\mathrm{pH} 4.5) \\
(50: 50)\end{array}$ & 240 & $\begin{array}{l}5-2500 \\
\mathrm{ng} / \mathrm{ml}\end{array}$ & [24] \\
\hline $\begin{array}{l}\text { UFLC Acetonitrile: Phosphate } \\
\text { buffer (pH 6.8) (50:50) }\end{array}$ & 241 & $20-100$ & [25] \\
\hline UPLCAcetonitrile: Water (35:65) & 240 & $2.5-200$ & [26] \\
\hline
\end{tabular}

Table 2: Review of liquid chromatographic methods for dosage forms.

\begin{tabular}{|l|c|c|c|c|}
\hline \multicolumn{1}{|c|}{ Mobile phase (v/v) } & $\boldsymbol{\lambda} \mathbf{( n m )}$ & Linearity & Sample & Ref \\
\hline Methanol: Water (70:30) & 239 & $\begin{array}{c}0.15-100 \\
\mu \mathrm{g} / \mathrm{ml}\end{array}$ & $\begin{array}{c}\text { Wistar rat } \\
\text { serum }\end{array}$ & {$[27]$} \\
\hline $\begin{array}{l}\text { Acetonitrile: Phosphate } \\
\text { buffer (35:65) (Fluores- } \\
\text { cence technique) }\end{array}$ & $\begin{array}{c}230 \\
\text { (Excitation) } \\
295\end{array}$ & $\begin{array}{c}0.5-80 \\
\mathrm{ng} / \mathrm{ml}\end{array}$ & $\begin{array}{c}\text { Human } \\
\text { plasma }\end{array}$ & {$[28]$} \\
\hline $\begin{array}{l}\text { (Emission) } \\
\text { 75\% 0.02 M Phosphate } \\
\text { buffer (pH 5.5): 25\% }\end{array}$ & - & $\begin{array}{c}50.55- \\
\text { Acetonitrile }\end{array}$ & $\begin{array}{c}\text { Human } \\
\text { plasma }\end{array}$ & {$[29]$} \\
\hline $\begin{array}{l}\text { Acetonitrile: Phosphate } \\
\text { buffer (41:59) }\end{array}$ & 239 & $\begin{array}{c}2.48-99.2 \\
\mu \mathrm{m} / \mathrm{L}\end{array}$ & $\begin{array}{c}\text { Human } \\
\text { plasma }\end{array}$ & {$[30]$} \\
\hline $\begin{array}{l}\text { Phosphate buffer (pH } \\
\text { 6.8): Acetonitrile (56:44). }\end{array}$ & 242 & $\begin{array}{c}0.2-20 \mu \mathrm{g} / \\
\mathrm{ml}\end{array}$ & $\begin{array}{c}\text { Blood } \\
\text { plasma }\end{array}$ & {$[31]$} \\
\hline
\end{tabular}

Table 3: Review of liquid chromatographic methods for biological samples.

\begin{tabular}{|l|c|c|c|}
\hline \multicolumn{1}{|c|}{ Mobile phase } & $\begin{array}{c}\text { Linearity } \\
\text { (ng/ml) }\end{array}$ & Sample & Ref \\
\hline $\begin{array}{l}\text { 0.1\% formic acid in water (pH 3.3): } \\
\text { 0.1\% formic acid in methanol }\end{array}$ & $1.0-60.0$ & $\begin{array}{c}\text { Human } \\
\text { plasma }\end{array}$ & {$[32]$} \\
\hline $\begin{array}{l}\text { Acetonitrile - 0.1\% formic acid in } \\
\text { water }\end{array}$ & $2-2000$ & $\begin{array}{c}\text { Rat } \\
\text { plasma }\end{array}$ & {$[33]$} \\
\hline $\begin{array}{l}\text { Methanol: 10 mM Ammonium } \\
\text { acetate (65:35) }\end{array}$ & $0.40-50.0$ & $\begin{array}{c}\text { Human } \\
\text { plasma }\end{array}$ & {$[34]$} \\
\hline $\begin{array}{l}\text { Acetonitrile: Formic acid (0.2\% } \\
\text { aqueous) (70:30) }\end{array}$ & $0.25-100$ & $\begin{array}{c}\text { Human } \\
\text { blood } \\
\text { plasma }\end{array}$ & {$[35]$} \\
\hline $\begin{array}{l}\text { 10mM Ammonium acetate: Acetoni- } \\
\text { trile (pH 3.0) (10:90) }\end{array}$ & $0.2-100$ & $\begin{array}{c}\text { Human } \\
\text { plasma }\end{array}$ & {$[36]$} \\
\hline $\begin{array}{l}\text { Methyl terta - butyl ether (TBME) } \\
\text { with methanol }\end{array}$ & $1.56-200$ & $\begin{array}{c}\text { Human } \\
\text { plasma }\end{array}$ & {$[37]$} \\
\hline $\begin{array}{l}\text { 15 mM ammonium format contain- } \\
\text { ing 0.1\% formic acid: Acetonitrile }\end{array}$ & $10-500$ & $\begin{array}{c}\text { Human } \\
\text { Urine }\end{array}$ & {$[38]$} \\
\hline $\begin{array}{l}\text { Methanol: 0.1\% Formic acid in } \\
\text { water (85:15) }\end{array}$ & $0.10-100$ & $\begin{array}{c}\text { UPLC } \\
\text { Human } \\
\text { plasma }\end{array}$ & {$[39]$} \\
\hline
\end{tabular}

Table 4: Review of LC - MS/MS methods.

\section{Conclusion}

Different analytical methods such as HPTLC, UV, HPLC, UPLC, UFLC, Capillary electrophoresis and hyphenated techniques such as LC-MS and LC-MS/MS methods were reported for the estimation of Letrozole in bulk, pharmaceutical formulations and biological samples. This review article will be very useful for the researchers to compare any new analytical method developed with that of the previously available methods for the estimation of Letrozole. 


\section{Bibliography}

1. Crucitta E., et al. "The role of Letrozole (Femara(R)) in breast cancer therapy: A clinical review". Drugs Today (Barc) 37.9 (2001): 639-644.

2. Miller WR., et al. "Aromatase Inhibitors: Are there differences between steroidal and nonsteroidal aromatase inhibitors and do they matter?" The Oncologist 13.8 (2008): 829-837.

3. Bhatnagar AS. "The discovery and mechanism of action of Letrozole". Breast Cancer Research and Treatment 105.1 (2007): 7-17.

4. Tamilselvi N., et al. "Development and validation of HPTLC method for the determination of Letrozole in bulk and tablet dosage form". World Journal of Pharmaceutical Research 5.1 (2015): 884-893.

5. Ganesh M., et al. "A validated UV spectrophotometric method for the determination of Letrozole in bulk and solid dosage form". Rasayan Journal of Chemistry 1.1 (2008): 55-58.

6. Siddharth MP., et al. "Development of UV spectrophotometric method for estimation of Letrozole in pure and pharmaceutical dosage form". Indo American Journal of Pharmaceutical Research 8.4 (2018): 1080-1085.

7. Ghosal SK., et al. "Development and validation of a spectrophotometric method for estimation of Letrozole in bulk and pharmaceutical formulation". Die Pharmazie - An International Journal of Pharmaceutical Sciences 62.8 (2007): 597-598.

8. Suryakanta S., et al. "Validated UV spectrophotometric methods for the estimation of Letrozole in solid dosage forms". International Journal of Pharmaceutical Sciences and Nanotechnology 11(2018): 4129-4135.

9. Dange YD., et al. "Simultaneous equation method for the estimation of Palbociclib and Letrozole by UV-visible spectrophotometry". Indian Drugs 54.9 (2017): 61-66.

10. Acharjya SK., et al. "Spectrophotometric methods for the determination of Letrozole in bulk and pharmaceutical dosage forms". Journal of Advanced Pharmaceutical Technology and Research 1.3 (2010): 348-353.

11. Hari PR., et al. "Forced degradation study of Letrozole-a validated stability indicating HPLC assay for bulk and tablet dosage form". International Journal of Pharmacy and Pharmaceutical Sciences 4.2 (2012): 582-586.

12. Annapurna MM., et al. "Stability-indicating liquid chromatographic method for the determination of Letrozole in pharmaceutical formulations". Journal of Pharmaceutical Analysis 2.4 (2012): 298-305.
13. Elkady EF and Fouad MA. "Preparation and characterization of two new forced degradation products of Letrozole and development of a stability-indicating RP-LC method for its determination". Pakistan Journal of Pharmaceutical Sciences 28.6 (2015): 2041-2051.

14. Nataraj KS., et al. "Stability indicating analytical method development and validation for related substances for Letrozole tablets by RP-HPLC". Research Journal of Pharmaceutical, Biological and Chemical Sciences 3.4 (2012): 658-676.

15. Mondal N., et al. "Development and validation of RP-HPLC method to determine Letrozole in different pharmaceutical formulations and its application to studies of drug release from nanoparticles". Acta Poloniae Pharmaceutica 66.1 (2009): 11-17.

16. Kaplan C and Durisehvar OU. "A validated method without derivatization for the determination of Letrozole by high performance liquid chromatography-fluorimetric method for pharmaceutical preparation". Istanbu Journal of Pharmacy 48.2 (2018): 38-42.

17. Pallavi S., et al. "Development and validation of RP-HPLC method for the determination of Letrozole in bulk and dosage form". International Research Journal of Pharmacy 3.11 (2012): 202-204.

18. Annapurna MM., et al. "New RP-HPLC method for the quantification of Letrozole (an anti-cancer agent)". Acta Scientific Pharmaceutical Sciences 3.8 (2019): 106-109.

19. Anand S., et al. "Development of validated RP-HPLC method for determination of Letrozole in bulk and its pharmaceutical dosage forms". Der Pharmacia Sinica 2.2 (2011): 263-269.

20. Laha TK., et al. "Reverse phase high performance liquid chromatographic method for the analysis of Letrozole in pharmaceutical dosage forms". Indian Journal of Pharmaceutical Sciences 70.3 (2008): 401-403.

21. Ganesh M., et al. "Determination of Letrozole in tablet formulations by reversed phase high performance liquid chromatography". Tropical Journal of Pharmaceutical Research 9.5 (2010): 505-510.

22. Moussa BA., et al. "Determination of Letrozole in pharmaceutical preparation and human plasma based on fluorometric detection". Analytical chemistry letters 3 (2013): 139-146.

23. Chun-li WU., et al. "Determination of content uniformity of Letrozole in Letrozole orally disintegrating tablets by HPLC". Chinese Journal of Hospital Pharmacy 7 (2007): 910-912. 
24. Aswathi RH., et al. "Full factorial experimental design for development and validation of a RP-HPLC method for estimation of Letrozole in nano formulations". Current Pharmaceutical Analysis 14.3 (2018): 320-330.

25. Nahida fazilath SK and Parthiban P. "Development and validation of RP-UFLC and UV spectro photometric for Determination of an anticancer drug Letrozole and its stability by RPUPLC". International Journal of Pharmacy and Pharmaceutical Analysis 1.3 (2017): 98- 112.

26. Ahmad YA., et al. "Development and validation of stability indicating simple RP-UPLC method for the determination of Letrozole in pharmaceutical dosage forms". National Biotechnology Conference, California (2013).

27. Sasmita Kumari., et al. "Development of a high performance liquid chromatographic method for determination of Letrozole in wistar rat serum and its application in pharmacokinetic studies". Scientia Pharmaceutica 80 (2012): 941-953.

28. Afshin Z., et al. "HPLC determination of Letrozole in plasma using fluorescence detection: application to pharmacokinetic studies". Chromatographia 66.9 (2007): 747-750.

29. Sekar V., et al. "Bioanalytical method development and validation of Letrozole by RP-HPLC method". International Journal of Pharmaceutical Research and Development 1 (2008): 1-8.

30. Yu-ting Z., et al. "HPLC determination of Letrozole in human plasma and study on bioavalibility of Letrozole dispersible tablets". Guide of China Medicine 4 (2010): 28-29.

31. Mohammad Kazem MN., et al. "Release and extraction of Letrozole in blood plasma using resorcinol functionalized multiwalled carbon nanotube coupled with high performance liquid chromatography". Journal of Liquid Chromatography and Related Technologies 41 (2018): 239-245.

32. Shao R., et al. "Development and validation of a rapid LC-MS/ MS method to quantify Letrozole in human plasma and its application to therapeutic drug monitoring". Biomedical Chromatography 30.4 (2015): 632-637.

33. Xuezhi Y., et al. "Determination of Letrozole in rat plasma by UPLC-MS/MS and its application to a pharmacokinetic study". Latin American Journal of Pharmacy 34.1 (2015): 45-50.

34. Jing S., et al. "Quantification of Letrozole in human plasma using LC-ESI-MS/MS with D4-Letrozole as internal standard: Application in a pharmacokinetic study". Journal of Liquid Chromatography and Related Technologies 36.13 (2013): 1762-1776.
35. Platova AI., et al. "Rapid and sensitive LC-MS/MS assay for quantitation of Letrozole using solid-phase extraction from human blood plasma and its application to pharmacokinetic studies". Pharmaceutical Chemistry Journal 48.4 (2014): 292297.

36. Joshi C., et al. "Validation and application of a high-performance liquid chromatography- tandem mass spectrometry assay for Letrozole in human plasma". Asian Journal of Pharmaceutical and Clinical Research 4.2 (2011):107-112.

37. Tapan Kumar P., et al. "Bioanalytical method development and validation of Letrozole by LC-ESI-MS/MS in human plasma". Journal of Analytical and Pharmaceutical Research 4.1 (2017): 00093.

38. Kang MJ., et al. "Validation and application of a screening method for $\beta 2$-agonists, anti-estrogenic substances and Mesocarb in human urine using liquid chromatography/tandem mass spectrometry". Rapid Communications in Mass Spectrometry 21.2 (2007): 252-264.

39. Vanol PG., et al. "SPE-UPLC-MS/MS assay for determination of Letrozole in human plasma and its application to bioequivalence study in healthy postmenopausal Indian women". Journal of Pharmaceutical Analysis 6.4 (2016): 276-281.

40. Rusu A., et al. "Letrozole determination by capillary zone electrophoresis and UV spectrophotometry methods". Acta Medica Marisiensis 63.2 (2017): 80-86.

\section{Assets from publication with us}

- Prompt Acknowledgement after receiving the article

- Thorough Double blinded peer review

- Rapid Publication

- Issue of Publication Certificate

- High visibility of your Published work

Website: https://www.actascientific.com/

Submit Article: https://www.actascientific.com/submission.php Email us: editor@actascientific.com

Contact us: +919182824667 